\title{
A STUDY OF THE RELATIONSHIP BETWEEN INSTITUTIONAL OWNERSHIP AND CAPITAL STRUCTURE: EVIDENCE FROM TURKEY
}

\author{
KURUMSAL SAHİPLIK İLE SERMAYE YAPISI ARASINDAKİ İLIŞKİ ÜZERİNE BİR \\ ÇALIŞMA: TÜRKİYE ÖRNEĞİ
}

\author{
Murat ÇİNKO* \\ Oytun Tansel KASABOĞLU**
}

\begin{abstract}
This paper investigates how institutional investors affect capital structures of Borsa Istanbul (BIST) firms. Data is gathered for the period between 2005 and 2013 for 150 firms. Prior years are not taken into consideration in order not to distort the data since inflationary accounting practices were applied in the market before 2005. Data is obtained from Bloomberg database and Central Registry Agency. Sample consists of 150 non-financial firms which have full data set for the research period. Panel data analysis is used to analyze 1,350 firm-year observations. Data is investigated for the relation between institutional ownership and financial leverage. The model has been designed such that financial leverage is dependent variable, and institutional ownership is explanatory variable. Control variables such as tangibility, size, tax, profit, liquidity and market value / book value have also been employed in the model. The result of the model shows that there is a significantly negative relationship between institutional ownership and financial leverage.
\end{abstract}

Keywords: Institutional Ownership, Financial Leverage, Emerging Market, Panel Data Analysis

JEL Classification: G30, G32

\section{Özet}

Bu çalışma, kurumsal yatırımcıların Borsa Istanbul'da (BIST) yer alan firmaların sermaye yapısını nasıl etkilediğini incelemektedir. 2005 ile 2013 yılları arasında 150 firma için data toplanmıştır. 2005 yılından önce enflasyon muhasebesi uygulaması yapıldığı için veriyi saptırmamak adına daha önceki dönem dataları kullanılmamıştır. Veri için Bloomberg ve Merkezi Kayıt Kuruluşu veritabanlarından bilgi alınmıştır. Örneklem kümesi finansal alanda olmayan ve tüm datası mevcut 150 firmadan

* Marmara University, Faculty of Business Administration, Department of Business Administration, E-mail: mcinko@marmara.edu.tr

* Master Student, Marmara University, Faculty of Business Administration, Department of Business Administration, E-mail: okasaboglu@yahoo.com 
oluşmaktadır. Panel veri analizi ile 1,350 şirket-yıl gözlemi analiz edilmiştir. Veri, kurumsal sahiplik ile finansal kaldıraç arasındaki ilişki için incelenmiştir. Modelde, finansal kaldıraç bağımlı değişken ve kurumsal sahiplik açıklayıcı değişken olarak tasarlanmıştır. Tutulabilirlik, büyüklük, vergi, kar, likidite ve piyasa değeri / defter değeri kontrol değişkenleri olarak yer almıştır. Modelin sonucunda kurumsal sahiplik ile finansal kaldıraç arasında anlamlı ve negatif bir ilişki görülmüştür.

Anahtar Kelimeler: Kurumsal Sahiplik, Finansal Kaldıraç, Gelişmekte olan Piyasalar, Panel Veri Analizi

JEL Sınıflaması: G30, G32

\section{Introduction}

Illiquidity is one of the most critical situation for a company. It might take the company to bankruptcy process. Capital structure plays important role from this perspective. Therefore, capital structure is one of the most important issues of corporate finance. Capital structure deals with how a company finance its assets and expenses. These can be financed by short-term, longterm loans or by equity. These instruments have different properties and conditions. In order to find optimal debt-equity mix, different theories and researches have been put forth.

Modern theories are discussed which are emerged after Modigliani and Miller's seminal paper "The Cost of Capital, Corporate Finance and the Theory of Investment." Modern theories are Trade-off Theory, Agency Cost Theory, Signaling Theory, Pecking Order Theory and Market Timing Theory. Furthermore, papers related to determinants of capital structure are discussed.

In addition to capital structure, ownership types are scrutinized. Institutional investors are important players of the capital markets. Their investments are not only in their own countries but distributed around the whole world. Therefore, throughout the literature, institutional investors are investigated to understand their effects in different contexts. During the literature review, most of the researchers search for the performance relations of ownership types. In this paper, their relation, if exists, with capital structure is examined.

\section{Literature Review}

The analysis of capital structure, which attempts to find optimal mix of debt and equity, has been an important area of financial research since capital structure changes firm's cost of capital, affects value of the company, is the source for assets, determines capital and interest payments, and finally cash outflow is critical since it may lead to bankruptcy of the firm. Besides, effects of different ownership types on the company are also another significant area.

Before Modigliani and Miller, there were other theories which tried to explain optimal debt and equity mix. These were called classical theories. Classical theories were focused on the lowest cost of capital. When the lowest cost of capital is found, firm value maximized. These theories 
are Net Income Approach, Net Operating Income Approach and Traditional Approach to Capital Structure.

Modern period starts with Modigliani and Miller's (MM hereafter) "The Cost of Capital, Corporate Finance and the Theory of Investment." Some of the major modern theories are Trade-off Theory, Agency Cost Theory, Signaling Theory, Pecking Order Theory, and Market Timing Theory.

\section{Modigliani and Miller Proposition I (1958)}

First proposition is irrelevance of the capital structure. Based on this proposition market value of a firm is not affected by capital structure of a firm. Excluding tax effects, value of a firm can be calculated by dividing net operating income to the rate appropriate to firm's risk class. Therefore, although capital structure decisions are vital for the firms and affect cash flow stream, do not change the value but the distribution of the cash flow between lenders and shareholders.

\section{Modigliani and Miller Proposition II (1988)}

Second proposition is about the relation of cost of debt and cost of equity. MM stated that there is a positive relation between expected return of the investors and leverage due to the risk increase for investors.

In conclusion, this theoretical approach with very strong assumptions does not reflect the reality. However, as Miller stated

\section{"showing what does not matter can also show, by implication, what does matter"}

these propositions put different perspective, led new theories to emerge and started modern period for theories of capital structure.

\section{Trade-off Theory}

Trade-off term is used by different researchers for related set of theories. In these theories, main idea is to analyze costs and benefits of different capital structure plans. The aim is to find a solution which balances marginal cost and marginal benefit. The original version of trade-off theory was structured on top of MM irrelevance proposition. After income tax and tax shield added to the theory, then optimal capital structure turned out to be $100 \%$ debt financing. Also, debt financing help reduce the agency cost. To avoid this extreme assumption, a balancing item was needed. Cost of financial distress is the disadvantage of the debt. There are direct and indirect costs of financial distress. Kraus and Litzenberger (1973) discussed Trade-Off Theory which is based on costs and benefits of debt. 
Agency Cost Theory

Jensen and Meckling (1976) discussed the theory in their paper about principal and hired agencies. There are principals and agencies in the companies. Principals would be shareholders or owners and agencies are directors or managers. Principals delegate some of their authorities to agents and they expect agents to work for maximization of shareholder's wealth. Agents may be challenged by opportunities and may not work fully for the interest of the company or principals. Instead, they may want to maximize their values even it decreases the wealth of the company.

\section{Signaling Theory}

Ross (1977) had different approach to MM's assumption of perfect markets by adding information asymmetry. Ross questioned how the dynamics of the market should be if not everyone has equal information. Managers or insiders are assumed to have more information about cash flows and profitability of their firm than outsiders. Therefore, the analysis made by the market with the available information to outsiders might not be enough to distinguish firms with two different prospects. Thus, two firms might be priced equally which is unfair to one with better prospects.

\section{Pecking Order Theory}

Myers and Majluf (1984) discussed the Pecking Order Theory as an alternative explanation for how a firm chooses their capital mixtures. There are three possible sources of financing. These are internal funds, debt and new equity. According to theory, internal funds should be preferred first, debt at the second step and finally new equity.

\section{Market Timing Theory}

Baker and Wurgler (2002) discussed the Market Timing Theory. Although, MM assumed that markets are efficient and competitive, in real world they are not. Market timing theory suggests that managers create their capital structure strategy based on responses to market perception of firm's current position. These responses might be in two ways. First one is that misperception of the market might cause the mispricing of assets, firm or shares. For instance, when stock prices are low, there is a tendency to equity repurchases. Second one is that adverse selection of Myers and Majluf (1984) which is based on information asymmetry. Since the insiders know the company and company's prospect better and before than outsiders, they might act before the market to benefit from expectations or excess information. For example, when they think that stocks are overvalued, they issue additional equity. 


\section{Ownership Types and Institutional Ownership}

Throughout the literature ownership types and their effects on different performance metrics of companies were analyzed. Behaviors of individuals, foreign investors, institutional investors, hedge funds, and corporates are some of the ownership types that were researched for.

Role of the institutional ownership grows significantly in capital markets. Aguilar (2013) gave the statistics from U.S. show that equities managed by institutional investors have risen from 7-8\% in 1950 to $67 \%$ in 2010 . The reason of the increase is that people want to invest in markets with pooled-investment vehicles.

In order to understand effects of institutional ownership, first of all it needs to be defined. Celik and Isaaksson (2013) mentioned that there is no clear definition for it. They continued that institutional investors are not physical people but they are organized as legal entities. However, their legal form varies widely such as joint stock companies, limited liability partnership, and incorporation by special statute. Davis and Steil (2004) defined as

"specialized financial institutions that manage savings collectively on behalf of small investors towards a specific objective in terms of acceptable risk, return maximization, and maturity of claims."

Gregoriou (2012) compared to individual investors and banks, institutional investors have different advantages. First of all, diversification can be made easily due to high trading volume. It is a risk-reduction strategy to enhance the portfolio with different kind of inputs. Portfolio should be diversified with assets with different movement tendencies. Second, banks try to match maturities of their assets and liabilities. Therefore, their investment capacity is limited. On the other hand, institutional investors may invest long-term liabilities as long as they are in line with their investment scheme. Third, compared to individuals, economies of scale lower costs of transactions for institutional owners from different aspects. Cost of experts is divided among investors. Thanks to higher volume there are lower commission rates applied. Finally, there is information asymmetry and institutions can have better access to knowledge.

\section{Methodology}

Panel data analysis is used to investigate the relations within data. Longitudinal data or cross sectional time series data are different names of panel data. A panel data contains set of data for each individual for different time periods. The importance of the panel data analysis is that it combines several years of data for cross-sectional observations.

Regression of panel data is different than both time series and cross-section regression. In the equation, there are two subscripts.

$$
Y_{\text {it }}=\alpha+X_{\text {it }} \beta+u_{\text {it }} \quad \mathrm{i}=1, \ldots, \mathrm{I} \quad \mathrm{t}=1, \ldots, \mathrm{T}
$$


where $Y_{\text {it }}$ is the dependent variable observed for individual i at time $\mathrm{t}, X_{i t}$ is the independent variable, $\alpha$ is the unobserved time-invariant individual effect, and $u_{i t}$ is the error term.

$$
u_{\mathrm{it}}=\mu_{\mathrm{i}}+v_{\mathrm{it}}
$$

where $\mu_{i}$ denotes the unobservable individual specific effect and $v_{i t}$ denotes the disturbance. (Baltagi, 2005, pp. 25)

There are two models in panel data analysis to solve unit effects. These are fixed effects model and random effects model. Fundamental difference of these two is originated from the role of the parameter estimate of a dummy variable. In a fixed effects model it becomes the part of the intercept and in a random effects model it becomes an error component. In both fixed and random effects model, slopes remain the same across group or time period.

In order to understand which technique to deploy, group effect, time effect and the combination of these two should be analyzed. If group and time effect has different intercepts in the equation then fixed effects model can be applied, if group and time effect have different disturbances then random effects model can be applied.

Fixed Effects Model:

$$
Y_{\text {it }}=\left(\alpha+\mu_{i}\right)+X_{\text {it }} \beta+v_{\text {it }} \quad i=1, \ldots, \mathrm{I} \quad t=1, \ldots, \mathrm{T}
$$

Fixed effects model assumes the same slopes and constant variance across individual and examines individual differences in intercepts. $\mu_{i}$ is allowed to be correlated with other regressors, since an individual specific effect is time invariant and accepted a part of the intercept. The fixed effect model is estimated by least squares dummy variable regression and within effect estimation methods.

F test or Wald Test can be done to test fixed effects model. Null hypothesis of the Wald Test is that all dummy parameters except for one for the dropped are all zero. If null hypothesis is not rejected for the test, Pooled Ordinary Least Squares (OLS) model is used. Otherwise, fixed effects model is used.

$$
\begin{gathered}
H_{0}: \mu_{1}=\ldots=\mu_{i-1}=0 \\
\mathrm{~F}(\mathrm{n}-1, \mathrm{nT}-\mathrm{n}-\mathrm{k})=\frac{\left(\varepsilon / \varepsilon_{\mathrm{pooled}}-\boldsymbol{\varepsilon} / \varepsilon_{L S D V}\right) /(\mathrm{n}-1)}{\left(\boldsymbol{\varepsilon} \varepsilon_{L S D V}\right) /(\mathrm{nT}-n-k)}
\end{gathered}
$$

Random Effects Model:

$$
Y_{\text {it }}=\alpha+X_{i t} \beta_{i}+\left(\mu_{i}+v_{i t}\right) i=1, \ldots, \mathrm{I} t=1, \ldots, \mathrm{T}
$$

where $\mu_{i}$ is a fixed or random effect specific to individual or time period.

Random effects model assumes that individual effect is not correlated with any regressor and random effects model estimates error variance specific to groups. Thus, $\mu_{i}$ is an individual specific random heterogeneity or a part of the composite error term. Therefore, this model can also be called an error component model. Slopes of regressors and intercept are the same across 
individual. Difference is stemmed from individual specific errors, not from their intercepts. Random effects model is estimated by generalized least squares if a covariance structure of an individual i, $\sum$, is known. Otherwise, feasible generalized least squares or estimated generalized least squares methods are used.

Breusch-Pagan LM Test can be done to test random effects model. The null hypothesis for Breusch-Pagan LM test is that individual-specific or time-specific error variance components are zero. If null hypothesis is not rejected for the test, Pooled Ordinary Least Squares (OLS) model is used. Otherwise, random effects model is used (Breusch and Pagan, 1980).

$$
\begin{gathered}
H_{0}: \sigma_{\mu_{i}}^{2}=0 \\
\mathrm{LM}_{\mu_{i}}=\frac{n T}{2(T-1)}\left[\frac{\tau^{2} \Theta \epsilon}{\epsilon^{\prime} \epsilon}-1\right]^{2} \sim X^{2}(1)
\end{gathered}
$$

Depending on the results of the Wald test and Breusch-Pagan LM test, following procedures are applied. If null hypothesis is not rejected for both tests, Pooled Ordinary Least Squares (OLS) model is used. If null hypothesis is not rejected for Breusch-Pagan LM test and rejected for F test, Fixed Effects model is used. If null hypothesis is not rejected for F test and rejected for Breusch-Pagan LM test, Random Effects model is used. If null hypothesis is rejected for both tests, Hausman Test is run (Park, 2011).

Table I: Methodology to Select the Model

\begin{tabular}{|l|l|l|l|}
\hline & & \multicolumn{2}{|c|}{ Breusch-Pagan LM Test $\left(H_{0}: \sigma_{\mu_{4}}^{2}=0\right)$} \\
\hline & Null Hypothesis & Not Rejected & Rejected \\
\hline \multirow{2}{*}{} & Not Rejected & Pooled OLS Model & Random Effects Model \\
\cline { 2 - 4 } & Rejected & & $\begin{array}{l}\text { Fixed and Random or select based } \\
\text { on Hausman Test }\end{array}$ \\
\hline
\end{tabular}

Hausman test is run to select between fixed or random effects. The null hypothesis is that random effects should be used and the alternative is fixed effects. It tests whether the unique errors are related with regressors (Green, 2008).

$$
L M=\left(b_{L S D V}-b_{\text {random }}\right)^{\prime} \hat{W}^{-1}\left(b_{L S D V}-b_{\text {random }}\right) \sim X^{2}(k)
$$

The non-existence of multicollinearity is one of the assumptions of least squares method (Gujarati and Porter, 2009). Multicollinearity issue has to be tested for the model. If absolute value of pairwise correlation coefficient is higher than 0.8 and significant, there is an issue of multicollinearity. In the appendix table 5, Pearson Correlation Matrix is given for the model's explanatory and control variables excluding outliers detected. No multicollinearity issue has been detected. 
When two or more error terms are correlated between different error terms are not all equal to zero, then error term is subject to serial correlation. The model is tested for autocorrelation. Wooldridge test is done for autocorrelation. First, pooled OLS is regressed in first difference and residuals are predicted. Then, the residuals are regressed on its first lag and coefficients on those lagged residuals are tested. (Wooldridge, 2010). Null hypothesis for Wooldridge test for autocorrelation is "no first-order autocorrelation". Since the p-value is lower than $1 \%$, the data has autocorrelation issue $(\mathrm{F}=77.87 \mathrm{p}=.000)$

Heteroscedasticity occurs when variance of error terms may vary over observations. In order to test heteroscedasticity, first the model is run. Then, Breusch and Pagan Lagrangian Multiplier for random effects is tested. Since the chi-square value is 1170.46 and p values than $1 \%$, the data is heteroscedastic.

The variables that are going to be used in the study are Leverage as a dependent variable, Institutional ownership as an independent and Size, Tangibility, Firm Size, Tax Rate, Profitability, Liquidity and Market value over Book Value as controlled variable.

\section{Empirical Findings}

Data is gathered for the period between 2005 and 2013 for 150 firms. Prior years are not taken into consideration in order not to distort the data since inflationary accounting practices were applied in the market before 2005 .

Data is measured yearly and it is a short panel which means number of firms are higher than number of years. The data is balanced which means all firms have data for all years. Same firms exist for each period thus the data is fixed panel not rotating. The data is arranged in the long form which means that first firm has data set for all years as different lines of data then second firm comes with all the data lines.

Data is obtained from Bloomberg database and Central Registry Agency (CRA). From Bloomberg database, total assets, total equity, fixed assets, operating income, total current assets, total current liabilities, market-to-book values, pretax income, and net income values are gathered for each year for each company. From CRA database, institutional investors' ratio is calculated among the whole investors. Sample consists of 150 non-financial firms which have full data set for the research period. Consecutive data is critical to create balanced panel data. Panel data analysis is used to analyze 1,350 firm-year observations. Stata 11 is used as a software package.

Outlier is a data point that is located far away from sample data. Data has to be clear off outliers. To define outliers, 1.5 Interquartile Ranges (IQRs) rule used which is any data point below the first quartile minus 1.5 IQR or above the third quartile plus 1.5 IQRs. Outliers have been omitted when running the model. Descriptive statistics for the data that do not have outlier is given in the Table 2. 
Table 2: Descriptive Statistics

\begin{tabular}{|c|c|c|c|c|c|}
\hline & Obs. & Mean & Std. Dev. & Min & Max \\
\hline \multicolumn{6}{|c|}{ Dependent Variable } \\
\hline LVRG & 973 & 0.47 & 0.20 & 0.05 & 0.98 \\
\hline \multicolumn{6}{|c|}{ Explanatory Variable } \\
\hline INST & 973 & 0.38 & 0.29 & 0.00 & 0.97 \\
\hline \multicolumn{6}{|c|}{ Control Variables } \\
\hline TANG & 973 & 0.36 & 0.19 & 0.00 & 0.91 \\
\hline SIZE & 973 & 5.81 & 1.34 & 2.63 & 9.07 \\
\hline TAX & 973 & 0.13 & 0.13 & 0.00 & 0.53 \\
\hline PROF & 973 & 0.05 & 0.07 & -0.14 & 0.25 \\
\hline LQDTY & 973 & 1.74 & 0.91 & 0.10 & 4.78 \\
\hline MVBV & 973 & 1.44 & 0.83 & 0.15 & 4.16 \\
\hline
\end{tabular}

The model to test the hypothesis "There is a significantly negative relationship between institutional ownership and financial leverage" is shown below.

$$
\begin{aligned}
& L V R G_{i t}=\beta_{0}+\beta_{1} I N S T_{i t}+\beta_{2} T A N G_{i t}+\beta_{3} S I Z E_{i t}+\beta_{4} T A X_{i t}+\beta_{5} P R O F_{i t} \\
& +\beta_{6} L Q D T Y_{i t}+\beta_{7} M V / B V_{i t}+\epsilon_{i t}
\end{aligned}
$$

where;

$L V R G_{\text {it }} \quad$ calculated as total liabilities over book value of total assets at year $\mathrm{t}$ for firm i

$I N S T_{i t} \quad$ calculated as the number of shares held by institutional investors as a share of total free float at year $t$ for firm $i$

$T A N G_{i t} \quad$ measured by the ratio of tangible assets to total assets at year $t$ for firm $\mathrm{i}$

$S I Z E_{\text {it }} \quad$ measured by natural logarithm of total assets at year $t$ for firm i

$T A X_{i t} \quad$ calculated as the ratio of charged taxes to earnings before taxes at year $\mathrm{t}$ for firm $\mathrm{i}$

$P R O F_{i t} \quad$ calculated as operating income over total assets at year $\mathrm{t}$ for firm $\mathrm{i}$

$L Q D T Y_{i t} \quad$ measured as total current assets over total current liabilities at year $\mathrm{t}$ for firm $\mathrm{i}$

$M V / B V_{\text {it }} \quad$ calculated as market value of firm's equity over book value of firms' equity at year $\mathrm{t}$ firm i

$\epsilon_{i t} \quad$ error term in year $t$ for firm $i$

I firm index

$t \quad$ year index

After outliers are cleared from the data set multicollinearity, autocorrelation and heteroscedasticity is checked. According to the correlation values among the independents there is no multicollinearity in the data set. However, autocorrelation and heteroscedasticity tests showed that there exists problem in the data set. Fixed or Random effect model is decided by the procedure of the Table 1. First of all $\mathrm{F}$ test is done and null hypothesis is rejected $(\mathrm{F}=17.34 \mathrm{p}$ value .000$)$. Then BreuschPagan LM test is applied and null hypothesis is also rejected (chi-square $=1170.46$ and $\mathrm{p}$-value 
.000). Since both of the tests reject the null hypothesis Hausman test is applied to decide the Fixed or Random effect model. The result of the Hausman test given in table 3 showed that Fixed effect model should be applied. Since the data have autocorrelation and heteroscedasticity issue "cluster (cross section identifier)" code inserted to Stata code to get robust estimate of the model.

Table 3: Hausman Test

\begin{tabular}{|cccc|}
\hline & Coefficients & \\
\hline & Fixed & Random & Difference \\
\hline INST & -0.0543 & -0.0747 & 0.0204 \\
\hline TANG & -0.2008 & -0.2486 & 0.0478 \\
\hline SIZE & 0.0859 & 0.0562 & 0.0297 \\
\hline TAX & -0.1533 & -0.2767 & 0.1234 \\
\hline PROF & -0.0891 & -0.0732 & -0.0159 \\
\hline LQDTY & 0.0262 & 0.0054 & 0.0208 \\
\hline$\chi^{2}$ & 248.76 & & \\
\hline Significance & 0.0000 & & \\
\hline
\end{tabular}

Because of the insignificance of the tax variable which is excluded from the model and model is deployed again and results are given in Table 4.

Table 4: The Results of Panel Data Analysis

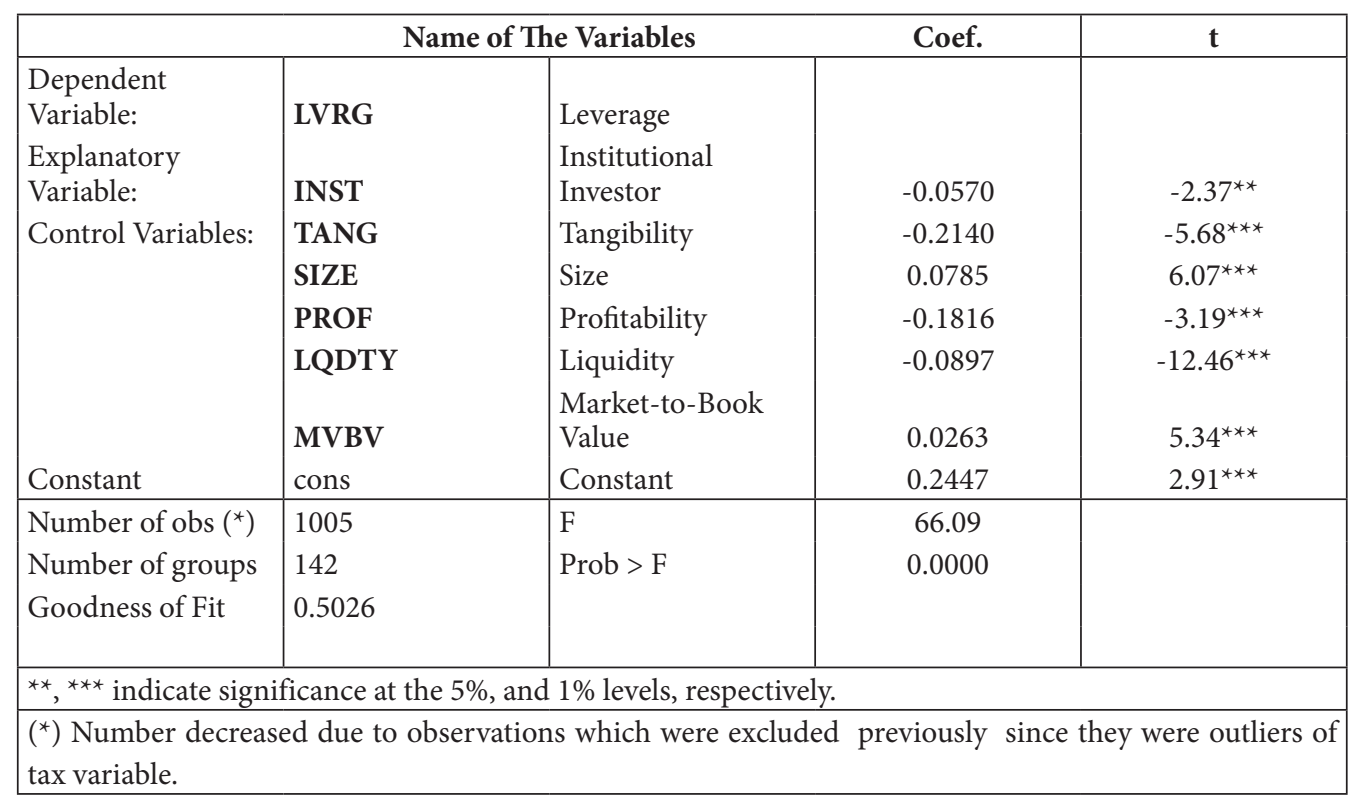

Null hypothesis of the F-test is that all coefficients in the model are zero. F-test shows that null hypothesis is rejected with significance less than $1 \%$. Thus, results can be interpreted. 
The explanatory variable in the model is INST which is denoted for institutional ownership ratio. There is a significantly negative relation ( $\mathrm{t}$-value $=-2.37, \mathrm{p}<0.05$ ). In other words, as institutional ownership ratio increases, financial leverage decreases. Michaely and Vincent (2012) show similar results and they investigate from both directions. They conclude that "firms in which institutions have a strong presence tend toward low leverage, and firms in which institutions strengthen their presence are associated with lower leverage". Tong and Ning (2004) use institutional investors as dependent variable with four different proxies. The proxy most relevant to our research is the percentage of institutional ownership of a firm which is proved to be insignificant. Based on the other proxies they conclude that firms with a low debt ratio tend to attract more institutional investors. Crutchley et al. (1999) conduct their analysis only for two years. In 1987, they find significantly positive relation between debt as a dependent variable and institutional ownership as an independent variable. In contrary, in 1993 they find significantly negative relationship. Hasan and Butt (2009) find that there is a positive relationship between institutional ownership and capital structure but it is statistically insignificant. To analyze the results with theories and literature, first increase in the ratio of institutional investors help increase in monitoring like creditors. Second, institutional investors do not want to invest in firms with very high level of leverage since it increases the bankruptcy risk and cost. If there is an increase in leverage ratios significantly, they might sell and exit. Third, attracting more institutional investors to the company could be an important sign of trust for the managers of the company. Thus, they can keep the leverage at low levels. These approaches are in line with the above negative relation between leverage and institutional ownership ratio.

The first control variable is TANG which refers to tangibility. There is a significantly negative relation ( $\mathrm{t}$-value $=-5.68, \mathrm{p}<0.01$ ). Pöyry and Maury $(2010)$ test tangibility using book value leverages and market value leverages. For both tests, they find significantly negative relations. $\mathrm{Li}$, Yue, and Zhao (2009) find significantly negative relation. Saylgan, Karabacak and Küçükkocaoğlu (2006) had expected positive relation for Turkish companies but their study resulted in a significantly negative relation. Xuan-Quang and Zhong-Xin (2013) state negative relation for tangibility but it is insignificant. De Jong, Kabir and Nguyen (2008) find that there is a positive relation at $10 \%$ significance level for Turkish companies. Michaely and Vincent (2012) also show positive relationship. Gurunlu and Gursoy (2010) also look for both book and market value leverages. They find correlations for both of them significantly positive. From theoretical perspective, it is expected to have positive relationship between leverage and tangibility since tangible assets can be used as a collateral which is important for creditors. Also, firms with high tangible assets ratio are less prone to bankruptcy risk. However, the result of the sample is not in line with theories.

SIZE is the second control variable which is the indicator of total asset size. There is a significantly positive relation ( $\mathrm{t}$-value $=6.07, \mathrm{p}<0.01$ ). Michaely and Vincent (2012), Xuan-Quang and Zhong-Xin (2013), Gurunlu and Gursoy (2010), Sayılgan, Karabacak and Küçükkocaoğlu (2006), Li, Yue, and Zhao (2009) and Céspedes, González, and Molina (2010) all find the relation significantly positive parallel to sample’s result. Pöyry and Maury (2010) find negative relation 
but results are insignificant. De Jong, Kabir, and Nguyen (2008) stated significantly negative relation. There are two theoretical approaches related to size. First, as size of the firm increases, information asymmetry increases. Therefore, managers want to use internal funds first, then external funds. Thus, leverage levels are expected to be low for large sized companies. On the other hand, bankruptcy risk is important component of trade-off theory. As size increases, the firm is less prone to bankruptcy risk. Therefore, it is expected to have high levels of leverage ratios for large sized companies. The result, found for the sample is in line with the second approach as size increases, leverage also increases.

The only control variable with insignificant relation is that TAX which is denoted for effective tax rate. $(\mathrm{t}$-value $=-0.57, \mathrm{p}>0.05)$. Although tax shield of interest paid is a very important factor, our sample has very different tax rates. The reason is that statutory tax amount is affected by previous years' losses carried and tax incentives benefitted. Arslan and Karan (2006) and De Jong, Kabir, and Nguyen (2008) find no significant relation. Céspedes, González, and Molina (2010) find negative relation but not all of their findings are significant. Tax shield is important aspect of leverage and trade-off theory. Interest payments are tax deductible and it decreases cost of debt. As effective tax rate increases, tax shield amount increases therefore cost of debt decreases. Thus, it is expected to have high levels of leverage as effective tax rate increases. In the tested sample, tax is found insignificant.

The other control variable is PROF which refers to profitability. There is a significantly negative relation (t-value $=-3.19, \mathrm{p}<0.01$ ). Li, Yue, and Zhao (2009), Céspedes, González, and Molina (2010), Sayllgan, Karabacak and Küçükkocaoğlu (2006), and Pöyry and Maury (2010) stated significantly negative relation parallel to sample's result. De Jong, Kabir, and Nguyen (2008) find negative relation but the result is not significant. There are two theoretical approaches for profitability of a firm. First, profitable firms are less prone to bankruptcy risk. Thus, they can obtain more leverage from creditors according to trade-off theory. Second, according to pecking order theory, firms should use internal funds first because of informational asymmetry. Profitability is the major source of internal funding. Therefore, it is expected to have low levels of leverage for profitable firms. The result, found for the sample is in line with the second approach, as profitability increases, leverage decreases.

LQDTY is another control variable. It is used to reflect the liquidity ratio. There is a significantly negative relation ( $\mathrm{t}-\mathrm{value}=-12.46, \mathrm{p}<0.01$ ). Dahlquist and Robertsson (2001) find the relation negative. De Jong, Kabir, and Nguyen (2008) also find negative relation but the result is not significant. Liquidity is a sign of accumulated cash and liquid assets. Therefore, it can be used as a first source of internal funding according to pecking order theory. Thus, as liquidity increases, leverage level should decrease. In the tested sample, liquidity is found negatively related to leverage which is in line with theories.

The last control variable is MVBV which refers to market value over book value. There is a significantly positive relation ( $\mathrm{t}$-value $=5.34, \mathrm{p}<0.01)$. Pöyry and Maury $(2010)$ and Gonenc 
(2003) find significantly positive relation of MVBV for book value leverage. De Jong, Kabir, and Nguyen (2008) and Tong and Ning (2004) find negative relation but it is insignificant. Dahlquist and Robertsson (2001) stated negative relation. According to signaling theory, firms want to issue equity instead of debt when market value is greater than book value in order to benefit from additional value. Therefore, there should be negative relation. On the other hand, market-tobook value can be used as a proxy for growth. If market-to-book value is greater than one, then it is a growth firm. Agency problems occur for growth firms. Increase in leverage help increase in monitoring facility of creditors. Thus, there should be positive relationship between growth and leverage. The result, found for the sample is in line with the second approach, as market-to-book value increases, leverage increases.

\section{Conclusion}

In this study, the relation of institutional ownership with capital structure is analyzed. Capital structure, itself, is one of the most important issues of corporate finance. Theories to identify optimal debt-equity mix have been developed throughout the literature. Modigliani and Miller's seminal paper started modern period for capital structure theories. Research and practices are continued in this area. Furthermore, ownership types and their performances are also deeply investigated area. In this study, rarely studied combination of these two aspects is combined and scrutinized.

To sum up, institutional ownership ratio has a significantly negative relation with leverage which is in line with studies of Michaely and Vincent (2012), Tong and Ning (2004) and partial data of Crutchley et al. (1999). Tangibility has a significantly negative relation in the sample which is not in line with trade-off theory since increase in tangibility is expected to ease increase in level of debt. Size and leverage relation is significantly positive. It is in line with trade-off theory which suggests that as size increases, the firm is less prone to bankruptcy risk. Tax has found insignificant in contrast to trade-off theory. Profitability has significantly negative relation with leverage. It is in line with pecking order theory. Liquidity has significantly negative relation with leverage which is in line with pecking order theory. Market-to-book value has significantly positive relation with leverage which is in line with the second theoretical approach of agency cost and monitoring. To conclude, throughout the literature, the same independent variables could lead to different results as a consequence of the selected years, countries and firms. For the period and for the selected companies, tested model produces significant results for all of the variables excluding tax. The hypothesis, significantly negative relation between financial leverage and institutional ownership is found after analysis. In other words, as institutional ownership ratio increases, financial leverage decreases. 


\section{Appendix}

Table 5: Pearson Correlation Matrix for Explanatory and Control Variables

\begin{tabular}{|l|l|l|l|l|l|l|}
\hline & INST & TANG & SIZE & TAX & PROF & LQDTY \\
\hline TANG & .02 & & & & & \\
\hline SIZE & $.56^{* * *}$ & .03 & & & & \\
\hline TAX & $.11^{* * *}$ & $-.07^{* *}$ & $.17^{* * *}$ & & & \\
\hline PROF & $.19^{* * *}$ & $-.14^{* * *}$ & $.20^{* * *}$ & $.45^{* * *}$ & & \\
\hline LQDTY & -.02 & $-.06^{* *}$ & $-.12^{* * *}$ & $.23^{* * *}$ & $.23^{* * *}$ & \\
\hline MVBV & $.21^{* * *}$ & $-.08^{* *}$ & .03 & .003 & $.15^{* * *}$ & $-.11^{* * *}$ \\
\hline
\end{tabular}

${ }^{\star *},{ }^{* * *}$ indicate significance at the $5 \%$, and $1 \%$ levels, respectively.

\section{References}

Arslan, Ö. and Karan, M.B. (2006). Ownership and Control Structure as Determinants of Corporate Debt Maturity: a Panel Study of an Emerging Market. Corporate Governance: An International Review, 14(4), 312-324.

Aguilar, L.A. (2013). Institutional Investors: Power and Responsibility. Securities and Exchange Commission, Speech (19 April): www. sec. gov/News/Speech/Detail/Speech/1365171515808.

Baltagi, B. (2005). Econometric Analysis of Panel Data. Chichester: John Wiley and Sons.

Baker, M. and Wurgler, J. (2002). Market Timing and Capital Structure. The Journal of Finance, 57(1): 1-32.

Breusch, T.S. and Pagan, A.R. (1980). The Lagrange Multiplier Test and Its Applications to Model Specification in Econometrics. The Review of Economic Studies, 47(1): 239-253.

Çelik, S. and Isaksson M. (2014). Institutional Investors and Ownership Engagement. OECD Journal: Financial Market Trends, 2013(2): 93-114.

Cespedes, J., Gonzalez, M. and Molina, C.A. (2010). Ownership and Capital Structure in Latin America. Journal of Business Research, 63(3): 248-254.

Crutchley, C.E., Jensen, M.R., Jahera, J.S. and Raymond, J.E. (1999). Agency Problems and the Simultaneity of Financial Decision Making: The Role of Institutional Ownership. International Review of Financial Analysis, 8(2): 177-197.

Dahlquist, M. and Robertsson, G. (2001). Direct Foreign Ownership, Institutional Investors, and Firm Characteristics. Journal of Financial Economics, 59(3): 413-440.

Davis, E.P. and Steil, B. (2004). Institutional Investors. Cambridge, MA: MIT press.

De Jong, A., Kabir, R. and Nguyen, T.T. (2008). Capital Structure Around the World: The Roles of Firm-and Country-Specific Determinants. Journal of Banking and Finance, 32(9): 1954-1969.

Gonenc, H. (2003). Capital Structure Decisions under Micro Institutional Settings: the Case of Turkey. Journal of Emerging Market Finance, 2(1): 57-82.

Green, W.H. (2008). Econometric Analysis. New Persey: Pearson Prentice Hall.

Gregoriou, G.N. (Ed.) (2012). Reconsidering Funds of Hedge Funds: The Financial Crisis and Best Practices in UCITS, Tail Risk, Performance, and Due Diligence. Academic Press.

Gujarati, D.M, and Porter, D.C. (20099. Basic Econometrics. New York: McGraw-Hill Companies. 
Gurunlu, M. and Gursoy, G. (2010). The Influence of Foreign Ownership on Capital Structure of NonFinancial Firms: Evidence from Istanbul Stock Exchange. IUP Journal of Corporate Governance, 9(4): 21.

Hasan, A. and Butt, S.A. (2009). Impact of Ownership Structure and Corporate Governance on Capital Structure of Pakistani Listed Companies. International Journal of Business and Management, 4(2): 50-57.

Jensen, M.C. and Meckling, W.H. (1976). Theory of the Firm: Managerial Behavior, Agency Costs and Ownership Structure. Journal of Financial Economics, 3(4): 305-360.

Kraus, A. and Litzenberger, R.H. (1973). A State-Preference Model of Optimal Financial Leverage. The Journal of Finance, 28(4): 911-922.

Li, K., Yue, H. and Zhao, L. (2009). Ownership, Institutions, and Capital Structure: Evidence from China. Journal of Comparative Economics, 37(3): 471-490.

Michaely, R. and Vincent, C. (2012). Do Institutional Investors Influence Capital Structure Decisions?. Johnson School Research Paper Series.

Miller, M.H. (1988). The Modigliani-Miller Propositions After Thirty Years. The Journal of Economic Perspectives, 2(4): 99-120.

Modigliani, F. and Miller, M.H. (1958). The Cost of Capital, Corporation Finance and the Theory of Investment. The American Economic Review, 48(3): 261-297.

Myers, S.C. and Majluf, N.S. (1984). Corporate Financing and Investment Decisions When Firms Have Information That Investors do not Have. Journal of Financial Economics, 13(2): 187-221.

Park, H. M. (2011). Practical Guides to Panel Data Modeling: a Step-by-Step Analysis Using Stata. Public Management and Policy Analysis Program, Graduate School of International Relations, International University of Japan.

Pöyry, S. and Maury, B. (2010). Influential Ownership and Capital Structure. Managerial and Decision Economics, 31(5): 311-324.

Ross, S.A. (1977). The Determination of Financial Structure: the Incentive-Signalling Approach. The Bell Journal of Economics, 8(1): 23-40.

Sayılgan, G., Karabacak, H. and Küçükkocaoğlu, G. (2006). The Firm-Specific Determinants of Corporate Capital Structure: Evidence from Turkish Panel Data. Investment Management and Financial Innovations, 3(3): 125-139.

Tong, S. and Ning, Y. (2004). Does Capital Structure Affect Institutional Investor Choices?. The Journal of Investing, 13(4): 53-66.

Xuan-Quang, D. and Zhong-Xin, W. (2013). Impact of Ownership Structure and Corporate Governance on Capital Structure: The Case of Vietnamese Firms. Australian Journal of Business and Management Research, 3(3): 11.

Wooldridge, J. M. (2010). Econometric Analysis of Cross Section and Panel Data. Cambridge, MA: MIT press. 
